\title{
Golden Tides: Problem or Golden Opportunity? The Valorisation of Sargassum from Beach Inundations
}

\author{
John J. Milledge * and Patricia J. Harvey \\ Algae Biotechnology Research Group, School of Science, University of Greenwich, Central Avenue, \\ Chatham Maritime, Kent ME4 4TB, UK; P.J.Harvey@greenwich.ac.uk \\ * Correspondence: j.j.milledge@gre.ac.uk; Tel.: +44-0208-331-8871 \\ Academic Editor: Magnus Wahlberg \\ Received: 12 August 2016; Accepted: 7 September 2016; Published: 13 September 2016
}

\begin{abstract}
In recent years there have been massive inundations of pelagic Sargassum, known as golden tides, on the beaches of the Caribbean, Gulf of Mexico, and West Africa, causing considerable damage to the local economy and environment. Commercial exploration of this biomass for food, fuel, and pharmaceutical products could fund clean-up and offset the economic impact of these golden tides. This paper reviews the potential uses and obstacles for exploitation of pelagic Sargassum. Although Sargassum has considerable potential as a source of biochemicals, feed, food, fertiliser, and fuel, variable and undefined composition together with the possible presence of marine pollutants may make golden tides unsuitable for food, nutraceuticals, and pharmaceuticals and limit their use in feed and fertilisers. Discontinuous and unreliable supply of Sargassum also presents considerable challenges. Low-cost methods of preservation such as solar drying and ensiling may address the problem of discontinuity. The use of processes that can handle a variety of biological and waste feedstocks in addition to Sargassum is a solution to unreliable supply, and anaerobic digestion for the production of biogas is one such process. More research is needed to characterise golden tides and identify and develop commercial products and processes.
\end{abstract}

Keywords: Sargassum; Phaeophyceae; beach-cast; seaweed; macroalgae; golden tide

\section{Introduction}

The number of inundations of beaches by seaweed has been increasing dramatically over recent years with these "seaweed tides" causing economic disruption to tourism, aquaculture, and traditional fisheries [1]. Seaweed inundations of the shoreline can be various described as green, red, or golden tides depending on the colour of the seaweed. Despite the large number of species of seaweeds, two genera are responsible for the majority of shoreline inundation incidents: Ulva, a green seaweed causing green tides, and a golden/brown floating or pelagic seaweed, Sargassum, causing golden tides, particularly in the Caribbean and West Africa [2].

There are a large number of species of the genus Sargassum (>350) [3]; most have a mature phase that grows anchored to the bottom of the sea by a root-like structure, the holdfast. Two species, S. natans and S. fluitans, are holopelagic and the predominate species in golden tides. They both reproduce vegetatively and never attach to the seafloor during their lifecycle [4]. Both species are golden brown and characterised by numerous blades, a highly branched thallus, and air bladders [5]. Typically $S$. natans has a delicate fine leaf structure, whereas $S$. fluitans has large lanceolate (lance like) leaves with $S$. fluitans having "thorns". S. natans has smooth stems, but each species exhibits a diversity of morphological forms with variation in blade and bladder shape $[2,5,6]$.

Pelagic Sargassum (Gulfweed) has been described as a floating jungle or golden floating rainforest as it is important for a diverse range of invertebrates, fishes, sea turtles, birds, and mammals, with over 
145 species of invertebrates and 100 species of fishes being associated with it [2,7]. The National Marine Fisheries Service has designated floating mats of Sargassum as an essential fish habitat [5]. Sargassum is not only of ecological importance, but has a global role in ocean sequestration of carbon, with the Sargassum of the Sargasso Sea being a net sink of $\mathrm{CO}_{2}$, representing $\sim 7 \%$ of the global net "carbon pump" [2].

The amount of Pelagic Sargassum in the ocean is huge, and thus the potential for golden tides is as well. The Sargasso Sea, so called due to the abundance of Sargassum, is the greatest aggregation of seaweed in the world with a total biomass of 10 million tonnes [5]. Around 1 million tonnes of Sargassum leaves the Gulf Mexico via the Florida Straits and enters the Sargasso Sea area of the Atlantic Ocean annually [7]. However, the Sargasso Sea and Gulf of Mexico are not the only sources of the golden tides in the Caribbean; a new source has been identified from the Northern Equatorial Recirculation Region (NERR) [4,6]. During the inundation of the Caribbean in 2015, 10,000 wet tonnes of seaweed was being dumped on beaches of the Caribbean islands daily [8]. However, inundations are not restricted to the Caribbean, but also occur on the beaches of the Gulf of Mexico, the Atlantic Coast of the USA, and the shoreline of western Africa from Morocco (South of Casablanca) to the Gulf of Guinea $[4,9,10]$. Prior to 2011 there had been no reports of golden tides on the shores of northwest Africa $[1,10]$. The exact reason for the Sargassum inundations of recent years are not fully known, although climate change and coastal sea eutrophication are implicated $[1,10,11]$, and it is not known if the major golden tides of 2011-2015 will continue to happen every year [12].

Deposits of Sargassum occur naturally and regularly on beaches, albeit in smaller quantities than the major golden tides of 2011-2015. They play a role in stabilising beaches and providing nutrients for beach and dune plants $[13,14]$. The organisms they carry can be important sources of food for beach fauna [12]. In locations where small deposits of Sargassum have been left on the beach, it is eventually washed away or buried by wave action and the smell of decomposition reduced by rain [12]. Beach-cast Sargassum is not considered injurious to human health [12,15], although there have been some reports of minor skin and eye irritations [16,17]. Leaving Sargassum where it is may be a viable approach for small deposits, avoiding the cost and potential negative impacts of beach cleaning, such as sand removal and destruction of habitat. However, large deposits may not be acceptable to beach users, and may have negative environmental effects, smothering organisms such as turtle hatchlings [2,15].

Tourism was worth $\$ 29.2$ billion in on-shore spending in the Caribbean in 2014, and contributed over $80 \%$ of the regional GDP. Tourists are reported to be avoiding resorts affected by golden tides [18], and Sir Hilary Beckles, the Vice Chancellor of the University of the West Indies, has described the inundation of Caribbean and Mexican Gulf beaches as "an international crisis" and "the greatest single threat" to the Caribbean $[8,19]$. However, the removal of Sargassum from beaches or the prevention of it reaching the beaches could be very costly. It has been estimated that it would take at least $\$ 120$ million to clean up the Sargassum inundations across the Caribbean based on the $\$ 5$ million spent on the clean-up of beaches in Mexico [8,19]. Galveston Island spends $\$ 3.5$ million annually on maintaining 32 miles of public beach by moving Sargassum from the main strand to less tourist-sensitive back areas of the beach to compost [20]. The prevention of seaweed reaching the beaches could also be costly, with 300-m floating booms estimated to cost $\$ 80,000$ to protect some of the beaches of St. Vincent and the Grenadines [21].

There are over 90 patents that refer to Sargassum, and it has been used for both fertiliser and animal feed [2]. Wild harvesting and cultivation of pelagic Sargassum in the Sargasso Sea for biofuel has been proposed [22-25]. However, commercial extraction of Sargassum from the Sargasso Sea is considered to pose a threat to the ecosystem, and currently there is no commercial extraction of Sargassum from the Sargasso Sea [2]. Although there have been some recommendations on how to remove Sargassum from beaches [12,20], there appears to be limited commercial exploitation with Sargassum only being used as a traditional local fertiliser, soil conditioner, and animal feed [15]. One of the key recommendations of the Caribbean Sea Commission [26] for addressing the threat of the Sargassum seaweed is to support research into commercial uses of Sargassum. The further exploitation of biomass is considered one of 
the best options for increasing renewable energy [27], and Sargassum collected from golden tides may be a potential source of bioenergy [12].

Sargassum muticum is a member of the Sargassum genus and an invasive species in Europe. Attempts to eradicate S. muticum have failed [28], and methods are being researched for its valorisation to encourage harvesting and control $[29,30]$. S. muticum has been suggested as a source of biochemicals, nutraceuticals, and pharmaceuticals [30,31]; a biorefinery feedstock [29]; and a biofuel feedstock [32-34]. The research and lessons learnt on S. muticum may be of value in seeking methods for the valorisation of the pelagic Sargassum species, S. natans and S. fluitans.

\section{Sargassum Composition and Potential Uses of Compounds}

Sargassum species and floating mats of Sargassum contain a wide range of biologically active compounds: sulphated polysaccharide, phenolics, plastoquinone, phlorotannins, fucoxanthin, fucoidan, sargaquinoic acid, sargachromenol, steroids, terpenoids, and flavonoids [16,35]. Various extracts from Sargassum species, including S. natans, showed significant therapeutic potential, suggesting Sargassum could provide novel functional ingredients for pharmaceuticals for the treatment and prevention of several disorders [35,36].

The ultimate composition and Higher Heating Value of S. natans is similar to that of S. muticum (Table 1).

Table 1. Ultimate analysis of S. muticum and S. natans.

\begin{tabular}{ccccccccc}
\hline & Ash & C & H & O & N & S & HHV & LHV \\
\hline & \multicolumn{9}{c}{$\% \mathrm{dw}$} \\
S. muticum $^{1}$ (Summer) $_{\text {S. }}$ (Satans & 33.3 & 30.1 & 4.2 & 28.1 & 3.6 & 0.8 & 12.0 & \\
S. $^{2}$ & 32.5 & 28.9 & 6.2 & 27 & 4 & 1.4 & $12.2 *$ & 9.7 \\
\hline
\end{tabular}

${ }^{1}$ [34]; ${ }^{2}$ [37]; * Calculated from LHV using the method of Demirel [38].

The heating values of both species are somewhat less than that of the terrestrial energy crops of $17-20 \mathrm{~kJ} \cdot \mathrm{g}^{-1} \cdot \mathrm{dw}$ [39] due to the high ash content. Adjusting for the ash content, the HHV of the volatile solids (VS) of both species is $\sim 18 \mathrm{~kJ} \cdot \mathrm{g}^{-1}$. The typical HHV of complex carbohydrates is $17.2 \mathrm{~kJ} \cdot \mathrm{g}^{-1} \cdot \mathrm{dw}$ and $21 \mathrm{KJ} \cdot \mathrm{g}^{-1} \mathrm{dw}$ for typical proteins [40]. The protein content can be estimated from the HHV data to be $\sim 11 \%$ of volatile solids and $\sim 7 \%$ of the dry weight $(\mathrm{dw})$ for both species.

\subsection{Proteins}

Brown seaweeds typically contain 3\%-16\% protein depending on the species and season [41,42]. The protein content of a biomass can be estimated from the nitrogen present by multiplying the $\mathrm{N}$ content by a factor ( $\mathrm{N}$ factor). The $\mathrm{N}$ factor is based on the proteins present in the biomass. A great many commonly occurring proteins contain $\sim 16 \%$ nitrogen and a factor of 6.25 has been most commonly used for foods [40] and is also widely used in algal literature [43]. However, there is a wide variation in the composition of protein in foods [40] and in particular algae [44,45]. Biomass may also contain a proportion of nitrogen that is not associated with proteins, but with compounds such as DNA, pigments, and free amino acids [44,46], and thus the commonly used multiplier of 6.25 causes the protein content to be overestimated [44,47]. Factors for common foods vary between 5.2 and 6.3 [40] and for algae 3.75-6.4 [44,48]. Overall $\mathrm{N}$ factors have been suggested for general use with algae of 5 [41], 4.78 [49], and 4.44 [44], and an average $\mathrm{N}$ factor for brown algae of 4.56 has been suggested in an extensive recent study by Angel et al. [41]. Using this latest $\mathrm{N}$ factor of 4.56, a protein content of $18 \%$ can be calculated for S. natans. The average protein content of S. fluitans is $12.8 \%$ [42]. Oyesiku and Egunyomi [16] found the protein content of pelagic mats of S. natans and S. fluitans, floating off the coast of Nigeria, to be $15.4 \%$.

Although both S. natans and S. fluitans are known to obtain a large proportion ( 44\%) of their nitrogen requirement from "ubiquitous" epiphytic cyanobacteria [50], there are considerable 
differences in the C:N ratio of pelagic seaweed depending on the availability of nutrients [5]. The average C:N ratio of Sargassum from the open ocean is 47, whereas in neritic water it is 27 [5]. The C:N for floating mixed Sargassum mats floating close to the coast of Nigeria can be estimated from the data of Oyesiku and Egunyomi [16] to be around 23. Although Lapointe et al. [5] found no significant difference between the $\mathrm{C}: \mathrm{N}$ ratio of $S$. natans and $S$. fluitans, the $\mathrm{C}: \mathrm{N}$ ratio found by Wan et al. [37] for S. natans was only 7. Milledge and Harvey [34] found the C:N ratio of S. muticum to be 8. The C:N ratio of S. muticum can vary between 6 and 20 depending on location and season [32,51,52]. A high C:N ratio could be advantageous for the production of biofuels, but a low $\mathrm{C}: \mathrm{N}$ ratio may be advantageous in the production of fertilisers and animal feeds.

Although seaweeds contain all 22 amino acids, they are generally rich in aspartic and glutamic acids, but limited in lysine, threonine, tryptophan, cysteine, and methionine [42] Although nutritional studies have shown that algal proteins are generally comparable to vegetable proteins [53], the imbalance of amino acids may limit the applicability of Sargassum as a foodstuff. A recent extensive review has found that the proteins, peptides, and amino acids from seaweed have shown positive bioactive effects in the treatment of diabetes, cancer, and AIDS, and the prevention of vascular diseases [54]. Considerable further research is required to identify polypeptides from pelagic Sargassum and their potential therapeutic benefits.

\subsection{Polysaccharides}

Sargassum can contain up to $68 \%$ polysaccharides [42], with the polysaccharide content of floating mats of Sargassum being 57\% [16]. The polysaccharide composition of brown seaweed is different to that of terrestrial plants, with the major polysaccharides of brown algae being laminarin, mannitol, alginate, fucoidan, and cellulose $[55,56]$.

\subsubsection{Alginates}

Alginates are a major component of the cell wall of brown algae, accounting for up to $40 \%$ of the dry weight [56]. They are U.S. Food and Drug Administration (FDA) approved polymers, and represent some of most important biomaterials for diverse applications, not only in the food and cosmetics industries, but also in the textile industry and for biomedical applications [57]. Worldwide annual alginate production has been estimated at 30,000 tonnes [58], and the uses of alginates have been extensively reviewed by Rehm [58], Bixler et al. [59], Holdt and Kraan [54], and Sun and Tan [57]. S. muticum has been used for alginate production $[60,61]$, but the yield is relatively low, $5 \%-11 \%$ compared to $16 \%-30 \%$ for commercially exploited brown algae $[62,63]$. Although there appears to have been some past exploitation of pelagic Sargassum for the production of hydrocolloids, the quality of alginic acid from Sargassum does not make it a viable source of commercial alginates, and there appears to be no current major commercial exploitation [64,65].

\subsubsection{Sulphated Polysaccharides}

The sulphated polysaccharides of seaweeds are chemically very different from those of land plants, with those in brown seaweed being mainly sulphated fucans (fucoidans), with other sulphated polysaccharides containing galactose, xylose, glucose, and other simple sugars also being found [66,67]. S. muticum contains $8 \%$ dry weight as fucans [68], with fucose being the dominant sugar in S. muticum sulphated polysaccharides [69]. Fucans have been classified as non-toxic. They have been shown to "aid" insoluble antioxidants, and they have been proposed as alternatives to the anticoagulant heparin [67]. Fucans can also inhibit the virus infection of cells and parasite invasion, showing antimalarial activity as well as inhibiting another widespread parasite, Toxoplasma gondii (the disease vector for toxoplasmosis) [67].

The structure of fucans can vary with the algal species, life-stage, and environment with the antioxidant capacity of the fucans related to their molecular mass and sulphate content [67]. Sulphated polysaccharides having a molecular mass $<30 \mathrm{kDa}$ have been shown to be the most biologically 
active, and sulphated polysaccharides of 26-35 kDa from Sargassum species have been shown to block carcinogens and display antiviral properties. Fucoidans from seaweeds can have a wide range of molecular masses, extending from 8 to at least $627 \mathrm{kDa}$ [61]. The molecular biology, biochemistry, and enzymology of fucan and fucoidan production in brown seaweeds and Sargassum, in particular, is a relatively underexplored area with considerable promise for future commercialisation [30]. S. natans has a sulphur content of $1.4 \% \mathrm{dw}$, and could contain a number of sulphated carbohydrates that may have potential commercial value. However, this relatively high sulphur content in Sargassum can have negative environmental impacts, with rotting Sargassum producing foul smelling and toxic hydrogen sulphide [26]. The organic sulphur in Sargassum can be completely lost from seaweed biomass as hydrogen sulphide under anaerobic conditions [34], and considerable care in the postharvest handling will be required to preserve sulphated carbohydrates.

\subsection{Lipids}

Macroalgal biomass typically has low lipid content, $0.3 \%-6 \%[24,70,71]$, and the lipid content of Sargassum is also low. S. muticum has a lipid content $<1.3 \%[72,73]$ and S. natans has a lipid content of $1 \%$ [74], but the lipid content of the mixed biota of floating Sargassum mats was found to be $2.5 \%$ [16].

Humans and animals lack the requisite enzymes to synthesise polyunsaturated fatty acids (PUFAs) of more than 18 carbon atoms and must obtain them from food; they are, therefore, often known as essential fatty acids. A group of essential fatty acids known as omega-3s (a group of unsaturated fatty acids where a carbon double bond is in the third position from the methyl or omega end) are attracting a lot of attention currently, as they exhibit anti-inflammatory and antioxidant activity and other health benefits [74-76]. Seaweeds are rich in polyunsaturated fatty acids (PUFAs), although there is considerable variation in the lipid profile between species [30,42].

Van Ginneken et al. [74] found that S. natans lipids contained 50\% PUFAs, and the biomass was particularly rich in docosahexaenoic acid (DHA) (C22:6) at $1 \mathrm{mg} \cdot \mathrm{g}^{-1}$. DHA is used as a supplement in infant formulas and as an adult dietary supplement. It is essential for the proper functioning of human brains as adults, and for the development of the nervous system and visual abilities during the first six months of life [75].

Turner et al. [77] found that all species of organism, both heterotrophic and autotrophic, from floating Sargassum mats were rich in PUFAs, $16 \%-62 \%$ of the total fatty acid composition, but there was considerable variation in the fatty acid composition between species found within the floating mats. Levels of 20:5 (n3), 22:5 (n3), and 22:6 (n3) were significantly higher in the particulate matter, containing microalgae, found within the floating seaweed mats, compared to the Sargassum spp. or epiphytic algae. The predominant PUFAs in the tissue of invertebrates and vertebrates within the Sargassum mats were 18:2(n6), 20:4 (n6), 20:5(n3), 22:5(n3), 22:6(n3). In PUFAs the cis double bonds are the most frequently separated from each other by a single methylene group (methylene-interrupted polyenes). However, non-methylene-interrupted fatty acids have been found in low levels in Sargassum that may have anti-proliferation activity against cancer cells, but considerable more research is required [78-80]. Sargassum mats could be a potential valuable source of a wide variety of PUFAs for both animal and human nutrition, although the yields per unit of dry biomass could be low $\sim 0.5 \%$.

Despite the high concentration of PUFAs in seaweed, the main fatty acid of many seaweeds is the saturated fatty acid palmitic acid (16:0) [81]. Palmitic acid makes up $41 \%$ of the fatty acids in $S$ natans [74]. In S. muticum, palmitic acid constitutes $21.5 \%$ of the total fatty acids, and has been shown to have antimicrobial activity against bacteria and diatoms [82]. The free fatty acids extracted from Sargassum pallidum have considerable antimicrobial activity against bacteria, yeast, and fungi, with glycolipids and neutral lipids demonstrating "moderate" activity [83]. The exact mechanism of antimicrobial action is unknown, but specific algal fatty acids may initiate lipid peroxidation and inhibit fatty acid synthesis within bacteria [83]. 


\subsubsection{Sterols}

The use of sterols in managing high cholesterol levels and cardiovascular health is extremely topical [84,85]. A wide range of sterols (C16-C30) have been described in Sargassum spp. [86], and sterols from Sargassum spp. have been shown to have potent natural cholesterol-lowering activity $[87,88]$.

\subsubsection{Carotenoids}

Most brown seaweeds contain the carotenoid pigment fucoxanthin, which has important antioxidant, anti-inflammatory, anti-obesity, anti-tumour, and UV-preventative activities [89-91].

Gammone et al. [92] have recently reviewed the effect of various carotenoids (including fucoxanthin) on human health, and in particular cardiovascular health; Maeda [93] has reviewed the use of fucoxanthin for obesity and diabetes therapy; and Zorofchian et al. [94] have reviewed the anticancer and anti-tumour potential of fucoxanthin.

Despite fucoxanthin being the main carotenoid produced by brown seaweeds, and its demonstrated benefits for human health, the biosynthetic pathway of fucoxanthin in seaweed is poorly understood; considerably more research is required to fully characterise the biochemistry and molecular biology of the enzymes that synthesise fucoxanthin, together with their structure and subcellular location $[95,96]$. However, fucoxanthin could be a major potential commercial product from Sargassum [97].

\subsubsection{Terpenoids and Phenolics}

A number of terpenoids and phenolic compounds have been found in Sargassum [16]. A group of phenolic terpenoids, meroditerpenoids (plastoquinones, chromanols, and chromenes), are found almost exclusively in the Sargassaceae and exhibit anti-tumour activity [98]. The phenolic compounds in brown algae play a primary role in the structure of cell walls and are generally considered to be a chemical defence against grazers, bacteria, fungi, and other epiphytes [99,100]. Sargassum spp. have been suggested as a sustainable source of bioactive phenolic compounds [101]. However, phenols in Sargassum may also be problematic as they can impart not only undesirable flavours but also can inhibit anaerobic digestion (AD) for the production of biogas [102,103].

\subsection{Inorganic Compounds}

Seaweeds generally contain high amounts of ash (inorganic material) $(9 \%-44 \% \mathrm{dw})$, with brown seaweeds also being generally rich in iodine $(>1.2 \% \mathrm{dw})$ relative to terrestrial plants and both red and green macroalgae [42]. S. natans typically has $\sim 30 \%$ ash [37].

The high ash content of Sargassum can provide minerals and trace elements that are beneficial in both fertiliser and animal feed $[16,65,104]$. In addition to macro- and micro-nutrients, seaweeds contain many growth-promoting hormones [105]. Growth of coastal plants increases with the use Sargassum as a fertiliser as it is a useful source of N, P, and K [13,16], and the use of Sargassum as a fertiliser is suggested as a positive, natural, and efficient method of dealing with golden tides [13]. However, the high ash content of Sargassum may be problematic for biofuels, especially direct combustion and gasification [71].

Iodine was extracted from kelp in Ireland from the seventeenth century [54], but the use of seaweed for the production of iodine has petered out due to competition from cheaper iodine from mineral deposits [106]. The iodine content of the biomass of floating Sargassum mats is relatively low $0.04 \mathrm{mg} \cdot \mathrm{g}^{-1} \cdot \mathrm{dw}$ compared to previously exploited species such as Laminaria japonica $[16,54]$, thus the commercial extraction of iodine from Sargassum would not appear to be a commercial viable target. However, the addition of Sargassum to the diet could be a useful supplementary source of iodine.

Seaweed can accumulate heavy metals from the environment, with metal concentrations in the seaweed biomass reaching values many times higher than their corresponding concentrations in seawater [107-109]. Sargassum can contain high levels of arsenic $\left(20-231 \mu \mathrm{g} \cdot \mathrm{g}^{-1} \cdot \mathrm{dw}\right)$ with inorganic 
arsenic accounting for up to $80 \%$ of the total arsenic content, and there have been a number of health advisories around the world warning against eating too much Sargassum, especially S. fusiforme [110]. The arsenic content of $S$. fluitans $\left(20 \mu \mathrm{g} \cdot \mathrm{g}^{-1}\right)$ is the lowest found for any Sargassum spp. studied [110]. However, care should be taken in incorporating Sargassum into the diet of both humans and animals to avoid increased heavy metal intake. Heavy metals in fertilisers may also accumulate in the soil, and high heavy metal content in seaweed may limit its value as a fertiliser [111].

The ability of both living and dead macroalgae to sequester heavy metals could be useful in the treatment of wastewater, with algae, especially the brown seaweeds, shown to be excellent biosorbents for heavy metals [112]. The high sorption capacity of brown seaweed and Sargassum is believed to be related to the polysaccharide composition of the cell wall $[109,113]$. Sargassum spp. including S. natans and S. fluitans have been shown to be effective biosorbents for a range of heavy metals including cadmium, lead, and gold [61,114,115]. Sargassum spp. have also been suggested as a low-cost biosorbent for the treatment of wastewater from industries that use dyes and phenolic compounds due to their high absorption capacity for phenolic compounds and industrial dyes such as methylene blue $[60,116,117]$.

\section{Processing Sargassum}

There has been discussion on how to collect Sargassum to minimise damage to beaches [12,20], but there appears to be little information on the post-harvest processing of golden tides.

\subsection{Cleaning and Sorting}

Beach-cast Sargassum is composed not only of S. natans and S. fluitans, but is a varied biota of epiphytes, bacteria, microalgae, and invertebrates, together with any marine pollution that has become entrapped. Once on the beach the organic material within the golden tide will begin to decompose. The decomposition and pollution, together with variable and undefined composition, may make golden tides unsuitable for food, nutraceutical, and pharmaceutical use, and considerable sorting and cleaning may be required for other applications. Sand in the biomass may also be problematic, having been shown to increase technical problems and reduce biomethane conversion efficiency in the pilot scale anaerobic digestion of seaweed [118]. The collection of Sargassum immediately offshore from the beach, such as that proposed in Guadeloupe [119], may eliminate much of the decomposition, but the variability of the feedstock and potential for pollutants being present will remain.

\subsection{Preservation}

The seasonal nature of golden tides will require a method of preserving Sargassum to provide a continuous supply, and the seasonal macroalgal growth is considered one of the major hurdles to the exploitation of seaweed for biofuel $[120,121]$. There are numerous methods used in food and agriculture to preserve organic materials, but two methods used to preserve large volumes of material are drying and ensiling.

\subsubsection{Drying}

The removal of water from the algal biomass by evaporation is very energy-intensive, requiring an energy input of $\sim 2.6 \mathrm{MJ} \cdot \mathrm{kg}^{-1}$ to heat water from 20 to $100{ }^{\circ} \mathrm{C}$ and evaporate it at atmospheric pressure [122]. Dewatering (the mechanical removal of water) generally uses less energy than evaporation, and thus it would appear preferable to minimise the water content of the harvested algae prior to drying. Although coal-fired driers have been used in Ireland for the production of seaweed-meal products [123], the use of fossil fuels to dry seaweed will be costly, have a negative energy balance, and produce unwanted greenhouse gas [32,124]. However, the cost of conventional drying could be reduced if 'waste' heat is available from power generation or large-scale refrigeration plant. 
Sun-drying is the main method of drying seaweed [125-127]. Clearly this approach does not require fossil fuel energy, but is both weather- and volume-dependent. Sun-drying in tropical locations may take 2-3 days in sunny weather, but could take up to seven days in rainy seasons [127]. Despite these limitations, solar methods are the least expensive drying option [128], but large areas are required as only around $100 \mathrm{~g}$ of dry matter can be produced from each square metre of surface [129].

Solar drying can cause considerable denaturisation of organic compounds in seaweed [130-133]. Freeze drying tends to cause less damage to organic materials, but is more expensive than solar or conventional drying, and is typically used for products such as premium instant coffee to give better flavour [134,135]. Freeze drying has been used for algae, particularly microalgae, such as Dunaliella, but is considered too expensive for the large-scale commercial recovery of algae, and its use is confined primarily to research and some high-value seaweed products [132,133,136,137].

\subsubsection{Ensilage}

An alternative preservation method is ensiling. It is routinely used for the storage of forage for animal feed. In ensilage lactic acid fermentation under anaerobic conditions converts water-soluble carbohydrates into organic acids, mainly to lactic acid. As a result the $\mathrm{pH}$ decreases and the moist crop is preserved [138]. Typically, ensiling conditions are achieved from spontaneous anaerobic lactic acid fermentation that is initiated by bacteria naturally present in the crop $[139,140]$. Dewatering and demineralisation are inherent features of ensiling [141] that may be of benefit for downstream processes such as anaerobic digestion, pyrolysis, and gasification.

Despite its widespread use in terrestrial agriculture there has been little research on how to preserve seaweed biomass year-round in order to satisfy continuous demand [142-144]. However, "an understanding of ensiling of seaweed is absolutely crucial for a substantial seaweed biofuel industry" [144]. There was some research into the ensilage of seaweed in the 1950s [142], and more recently in both Ireland and the United Kingdom [124,144]. A recent study of ensiling Sargassum muticum concluded that ensiling is an energy-efficient method of preserving seaweed for biofuel, and in particular biogas production, as energy losses are low $(<8 \%)$ and methane yields are not significantly reduced [34]. However, ensilage may cause changes to the composition of the biomass and the degradation of some organic compounds, and thus may not be suitable as a method of preservation for production of some high-value compounds, but lactic acid fermentation may yield novel pickled seaweed food products [143]. During ensilage virtually all the organic sulphur was removed from Sargassum muticum [34]. Low-sulphur feedstocks are favoured for both gasification and AD, and thus ensilage may yield downstream process benefits in biofuel production, but ensilage would not appear be an appropriate storage method if sulphated carbohydrates are the commercial target. The production of $\mathrm{H}_{2} \mathrm{~S}$ during ensilage will also have both operational and health and safety implications.

Although the $\mathrm{pH}$ values achieved in ensiling Sargassum (4.9-5.1) are similar to commercial grass silage produced in the Netherlands (4.5 to 5.8: average of 5.1), the $\mathrm{pH}$ achieved in seaweed ensilage may be insufficient to completely inhibit clostridial fermentation and the production of butyric acid, due to the high water content of seaweed silage relative to typical terrestrial forage crops [34,144,145]. Dewatering seaweed, as with drying, may also be advantageous prior to ensiling. Grass silage at a TS of $25 \%$ produces very little effluent, and thus potential pollution [146]. The United Kingdom's Ministry of Agriculture, Fisheries, and Food (MAFF) [147] has recommended that, in order to minimise effluent production, wilting to at least $25 \%$ dry matter prior to ensilage is required. Such wilting processes prior to ensilage also increases the concentration of sugars, which enhances the ease with which fermentation of the biomass occurs, whilst also reducing odours [147,148]. However, only rapid wilting $(<24 \mathrm{~h})$ offers benefits as slow wilting can lead to rotting and increased organic material losses [148]. The requirement to rapidly wilt seaweed prior to ensilage could have considerable influence on the operation, economics, and energy balance of macroalgal ensilage. 


\section{Biochar, Biofuels, and Biorefineries}

Sargassum has traditionally been recovered from beaches for use as both a fertiliser and animal feed [2], and this could remain a useful method of exploitation of golden tides. Although both fertiliser and animal feed can exploit the entire biomass, new markets will need to be found to exploit the potential volumes produced from inundations. Considerably more research will be required to establish whether the fertilisers and animal feeds from golden tides can meet relevant international quality and animal health standards. Transport costs could also considerably influence the economic competitiveness of these relatively low-value products [149].

\subsection{Biochar}

Another potential agricultural product could be biochar, defined as a solid material obtained from the carbonisation of biomass used to improve soil properties [150]. The differences between charcoal and biochar are primarily in the end uses, with charcoal being used as a fuel and biochar as a nonfuel [151]. Since the turn of the century biochar has received considerable attention, both from scientists and policy makers, as a soil enhancer to potentially increase agricultural yields and simultaneously sequester carbon to help mitigate climate change [152,153]. Biochar is produced by pyrolysis, the thermal decomposition of the organic component of dry biomass by heating in the absence of air $[154,155]$. The distribution between solid, liquid, and syngas depends on the biomass and the pyrolysis temperature and time. Lower temperatures (around $400{ }^{\circ} \mathrm{C}$ ) tend to produce more solid char (slow pyrolysis) $[122,156]$. The properties of the biochar are dependent not only on the pyrolysis conditions, but also on the feedstock [157]. Biochar has been produced experimentally from brown seaweeds including Sargassum spp., and has different properties to ligno-cellulosic biomass with relatively low carbon content and surface area, but with a high content of essential trace elements and exchangeable cations, particularly potassium [158]. The char from the pyrolysis of algae has been found to be an effective soil ameliorant and fertiliser [159], but the blending of seaweed and ligno-cellulosic chars could produce a soil ameliorant that has high fixed $\mathrm{C}$, together with a high mineral content, which may further enhance crop productivity [158]. The energy required for the pyrolysis of Sargassum could be provided by the syngas and bio-oil produced [32]. However, pyrolysis requires dry feedstock, and there is insufficient energy within Sargassum for drying, but the use of solar drying could result in a positive energy balance. Biochar will also have the advantage of reduced transport costs compared to dried seaweed fertiliser [160].

\subsection{Biofuel}

One way in which the extraction of energy from macroalgae can be categorised is according to whether an initial drying step is required or not. This leads to two distinct groups of processes:

(1) Energy extraction methods requiring dry macroalgae

(i) direct combustion

(ii) pyrolysis

(iii) gasification (conventional)

(iv) trans-esterification to biodiesel

(2) Energy extraction methods for wet macroalgae

(v) hydrothermal treatments

(vi) fermentation to bioethanol or biobutanol

(vii) anaerobic digestion

The methods of energy extraction from macroalgae have been recently reviewed and it was concluded that it is probably too early, at the current stage of biofuel development, to select definitively 
what method or combinations of methods for exploiting energy from macroalgae will be commercially exploited [71].

Direct combustion is, historically and currently, the main method by which energy from dry biomass resources is realised, providing heat or steam for household and industrial uses and for the production of electricity [161]. Macroalgal combustion does not appear to have been greatly explored [162,163]. However, the high energy required to dry seaweed, the relatively low thermal values, and the high ash and sulphur content can cause fouling and corrosion of boilers, and unacceptable emissions could preclude direct combustion as an economic method of exploiting seaweed $[71,162,163]$.

The higher lipid content of some microalgae compared to macroalgae has focused much of the published research work on the production of biodiesel from the microalgal lipids via trans-esterification $[122,164,165]$. Macroalgal biomass typically has lower lipid content, $0.3 \%-6 \%$ compared to microalgae, which can have $10 \%-70 \%$ [24,70,166,167]. Macroalgae would, therefore, not appear to be a suitable feedstock for the production of biodiesel via trans-esterification.

\subsection{Anaerobic Digestion}

Both gasification and anaerobic digestion have been suggested as promising methods for exploiting bioenergy from biomass [168]. A recent study that analysed four methods of microalgal bioenergy production found that anaerobic digestion produces more net energy than supercritical gasification, the latter requiring higher energy input and having a negative return on energy investment $[122,169]$. This conclusion is supported by a related study that has demonstrated that anaerobic digestion of "algal residues" can have a higher net energy return and much lower GHG emissions than gasification [170].

Seaweed-derived biogas was used industrially in the 19th century, and currently AD is perhaps closest to industrial exploitation [56,71,120,171]. Not only is it a relatively simple process from an engineering/infrastructure standpoint, but it has the potential to exploit the entire organic carbon content of macroalgae and can readily tolerate high moisture content without incurring additional process energy penalties. It is also readily scaled up [118]. A report for the Crown Estates has concluded that $\mathrm{AD}$ at a small, distributed scale was economically feasible for the co-digestion of seaweed with food waste [171]. The gasification of seaweed with wood-based biomass was also considered economically feasible. Conversely, the large-scale anaerobic digestion or gasification of seaweed alone was considered extremely challenging economically, and will require seaweed to be delivered to the processing plant at below $£ 300$ per tonne [171,172]. However, the biomass from golden tides has no cultivation cost, with the only costs prior to AD being for collection, sorting, and transport. The economics of the AD of seaweed could also be improved if it is part of a process that yields high-value products [173]. The residue remaining after the anaerobic digestion of seaweed, or digestate, is also considered to have considerable potential as fertiliser and could be an additional income source from the disposal of Sargassum [118].

The biomethane potential of Sargassum spp. is low at $\sim 0.13 \mathrm{~L} \cdot \mathrm{CH}_{4} \cdot \mathrm{g}^{-1} \cdot \mathrm{VS}[33,34,52]$, and considerably below that typical of seaweed at $0.2 \mathrm{~L} \cdot \mathrm{CH}_{4} \cdot \mathrm{g}^{-1}$.VS $[121,174,175]$ and $\sim 30 \%$ of that from common commercially exploited feedstocks [176-180]. There is considerable conjecture about the reasons for the relatively low practical methane yields compared to the theoretical values $[33,71,103,120,181]$, and more research is needed to find the cause of low methane yields and how to overcome them.

\subsection{Biorefineries}

A biorefinery concept that attempts to commercialise all the components of seaweed has been suggested as a more appropriate approach for the further exploitation of seaweed, rather than an approach based solely on the production of biofuel $[166,182,183]$. During the First World War, Hercules was producing 54 chemicals from seaweed; it closed shortly after the war when demand fell and alternative supplies became available [184]. As has been discussed previously, Sargassum has the potential to produce a wide range of high-value biochemicals, nutraceuticals, and pharmaceuticals. 
Despite this, there are still very few compounds commercially produced from seaweed, and the main product remains hydrocolloids [30,59,185-187]. Considerable more research is required to develop a commercially viable biorefinery for Sargassum.

\section{Co-Production}

The potential of the "failure" of golden tides to arrive in any year will require processes that are capable of exploiting other local biomass, or process plants could remain idle for long periods, considerably impacting on commercial viability. The ability to process two or more biomass feedstocks may also be advantageous-for example, the co-digestion of seaweed and another feedstock can enhance anaerobic biodegradability. Recent studies found that co-digestion of Sargassum spp. with glycerol or waste cooking oil containing little nitrogen increased methane production by $19 \%-56 \%$ compared to the individual materials digested separately $[34,188]$.

\section{Conclusions}

Although Sargassum has considerable potential as a source of biochemicals, feed, food, fertiliser, and fuel, variable and undefined composition together with the possible presence of marine pollutants may make golden tides unsuitable for food, nutraceuticals, and pharmaceuticals, and could limit their use in feed and fertiliser.

Discontinuous and unreliable supply of Sargassum also presents considerable challenges. Low-cost methods of preservation such as solar drying and ensiling may address the problem of discontinuity. The use of processes that can handle a variety of biological and waste feedstocks in addition to Sargassum is a solution to unreliable supply, and anaerobic digestion for the production biogas is one such process.

More research is needed to characterise golden tides and to identify and develop commercial products and processes.

Acknowledgments: This work was supported by the University of Greenwich, the EPSRC project number EP/K014900/1 ("MacroBioCrude: Developing an Integrated Supply and Processing Pipeline for the Sustained Production of Ensiled Macroalgae-derived Hydrocarbon Fuels") and the High Value Chemicals from Plants Network (HVCfP), a Biotechnology and Biological Sciences Research Council (BBSRC)-funded network in industrial biotechnology and bioenergy.

Author Contributions: Both authors contributed to research and writing of the manuscript.

Conflicts of Interest: The authors declare no conflict of interest.

\section{References}

1. Smetacek, V.; Zingone, A. Green and golden seaweed tides on the rise. Nature 2013, 504, 84-88. [CrossRef] [PubMed]

2. Laffoley, D.d'A.; Roe, H.S.J.; Angel, M.V.; Ardron, J.; Bates, N.R.; Boyd, L.L.; Brooke, S.; Buck, K.N.; Carlson, C.A.; Causey, B.; et al. The Protection and Management of the Sargasso Sea: The Golden Floating Rainforest of the Atlantic Ocean: Summary Science and Supporting Evidence Case; Sargasso Sea Alliance: St. George's, Bermuda, 2011.

3. Guiry, M.D.; Guiry, G.M.; Algaebase. World-Wide Electronic Publication. Available online: http://www. marinespecies.org/aphia.php?p=taxdetails\&id=144132 (accessed on 3 March 2016).

4. Oxenford, H.A. Sargassum moss: Ecological aspects and source of influx. In Sargassum Symposium; UWI, Cave Hill: Barbados, 2015.

5. Lapointe, B.E.; West, L.E.; Sutton, T.T.; Hu, C. Ryther revisited: Nutrient excretions by fishes enhance productivity of pelagic sargassum in the western North Atlantic Ocean. J. Exp. Mar. Biol. Ecol. 2014, 458, 46-56. [CrossRef]

6. Schell, J.M.; Goodwin, D.S.; Siuda, A.N.S. Recent Sargassum inundation events in the Caribbean shipboard observations reveal dominance of a previously rare form. Oceanography 2015, 28, 8-10. [CrossRef] 
7. Duncan, R.S. Southern Wonder: Alabama's Surprising Biodiversity; The University of Alabama Press: Tuscaloosa, AL, USA, 2013; p. 459.

8. Beckles, H. Greetings from the vice-chancellor. In Sargassum Symposium; UWI, Cave Hill: Barbados, 2015.

9. Stinking Seaweed that Smells of Rotten Eggs Invades Beaches in Florida and Texas-With Some Hit by Piles that Are 10ft High. Daily Mail. 18 October 2015. Available online: http:/ / www.dailymail.co.uk/news/article-3277720/Stinking-sargassum-seaweed-smells-rotten-eggsterrorizes-beaches-Caribbean-Florida-Texas-shores-experiencing-piles-kelp-10-feet-high.html (accessed on 9 September 2016).

10. Grass-Sessay, S.A. Concept Note on the Invasion of Pelagic Sargassum in West Africa, 2015. http://www.sargassoseacommission.org/storage/Concept_Note_on_Sargassum_Invasion_in_West_ Africa_-_UNEP_Abidjan_Convention_Secretariat.pdf (accessed on 9 September 2016).

11. Huffard, C.L.; Thun, S.; Sherman, A.D.; Sealey, K.; Smith, K.L. Pelagic Sargassum community change over a 40-year period: Temporal and spatial variability. Mar. Biol. 2014, 161, 2735-2751. [CrossRef] [PubMed]

12. Doyle, E.; Franks, J. Sargassum Fact Sheet; Gulf and Caribbean Fisheries Institute: Marathon, FL, USA, 2015.

13. Williams, A.; Feagin, R. Sargassum as a natural solution to enhance dune plant growth. Environ. Manag. 2010, 46, 738-747. [CrossRef] [PubMed]

14. BVI Government Information Service. Sargassum Seaweed: An Important Element for Beaches and Shoreline Stability. Available online: http://www.bvi.org.uk/government/pressrelease/remarkbydeputypremier (accessed on 12 October 2015).

15. Fiermonte, I. Sargassum a RESOURCE Guide for the Caribbean; The Caribbean Alliance for Sustainable Tourism (CAST): Coral Gables, FL, USA, 2015.

16. Oyesiku, O.O.; Egunyomi, A. Identification and chemical studies of pelagic masses of Sargassum natans (linnaeus) gaillon and S. fluitans (borgessen) borgesen (brown algae), found offshore in Ondo State, Nigeria. Afr. J. Biotechnol. 2014, 13, 1188-1193.

17. Willoughby, S. Sargassum and the fishing industry. In Sargassum Symposium; UWI, Cave Hill: Barbados, 2015.

18. Caribbean-Bound Tourists Cancel Holidays Due to Foul-Smelling Seaweed. The Guardian. 10 August 2015. Available online: https:/ /www.theguardian.com/environment/2015/aug/10/caribbean-bound-touristscancel-holidays-due-to-foul-smelling-seaweed (accessed on 9 September 2016).

19. Khan, A. Region Needs US $\$ 120 \mathrm{~m}$ to Fight Seaweed. Trinidad Daily Express. 18 August 2015. Available online: http://www.trinidadexpress.com/20150818/news/region-needs-us120m-to-fight-seaweed (accessed on 9 September 2016).

20. De Schaun, K. The summer of seaweed. In Sustainability Webinar Series; Caribbean Hotel \& Tourism Association: Coral Gables, FL, USA, 2015.

21. Plaguing Paradise: Smelly Piles of Seaweed Are Ruining Holidays. The Economist. 27 August 2015. Available online: http:/ / www.economist.com/news/americas/21662568-smelly-piles-seaweed-are-ruining-holidaysplaguing-paradise (accessed on 9 September 2016).

22. Werner, E.; Harris, J.A. Possible uses of pelagic seaweed as a mariculture substrate. Proc. Annu. Workshop World Maric. Soc. 1973, 4, 63-64. [CrossRef]

23. Hanisak, M.D.; Samuel, M.A. Growth rates in culture of several species of Sargassum from Florida, USA. Hydrobiologia 1987, 151, 399-404. [CrossRef]

24. Lenstra, W.J.; van Hal, J.W.; Reith, J.H. Economic aspects of open ocean seaweed cultivation. In Proceedings of the Alg'n Chem 2011, Montpellier, France, 7-10 November 2011.

25. N’Yeurt, A.d.R.; Chynoweth, D.P.; Capron, M.E.; Stewart, J.R.; Hasan, M.A. Negative carbon via ocean afforestation. Process Saf. Environ. Prot. 2012, 90,467-474. [CrossRef]

26. Caribbean Sea Commission. Challenges, Dialogue and Cooperation towards the Sustainability of the Caribbean Sea. In Proceedings of the 1st Symposium of the Caribbean Sea Commission, Port of Spain, Trinidad and Tobago, 23-24 November 2015.

27. Vargas-Moreno, J.M.; Callejón-Ferre, A.J.; Pérez-Alonso, J.; Velázquez-Martí, B. A review of the mathematical models for predicting the heating value of biomass materials. Renew. Sustain. Energy Rev. 2012, 16, 3065-3083. [CrossRef]

28. Josefsson, M.; Jansson, K. Nobanis-Invasive Alien Species Fact Sheet—Sargassum muticum. Available online: http://www.nobanis.org/files/factsheets/Sargassum_muticum.pdf (accessed on 4 November 2014). 
29. Balboa, E.; Moure, A.; Domínguez, H. Valorization of Sargassum muticum biomass according to the biorefinery concept. Mar. Drugs 2015, 13, 3745-3760. [CrossRef] [PubMed]

30. Milledge, J.J.; Nielsen, B.V.; Bailey, D. High-value products from macroalgae: The potential uses of the invasive brown seaweed, Sargassum muticum. Rev. Environ. Sci. Biotechnol. 2015, 15, 67-88. [CrossRef]

31. Rodrigues, D.; Freitas, A.C.; Pereira, L.; Rocha-Santos, T.A.P.; Vasconcelos, M.W.; Roriz, M.; Rodríguez-Alcalá, L.M.; Gomes, A.M.P.; Duarte, A.C. Chemical composition of red, brown and green macroalgae from Buarcos Bay in central west coast of Portugal. Food Chem. 2015, 183, 197-207. [CrossRef] [PubMed]

32. Milledge, J.J.; Staple, A.; Harvey, P. Slow pyrolysis as a method for the destruction of Japanese wireweed, Sargassum muticum. Environ. Nat. Resour. Res. 2015, 5, 28-36. [CrossRef]

33. Soto, M.; Vazquez, M.A.; de Vega, A.; Vilarino, J.M.; Fernandez, G.; de Vicente, M.E. Methane potential and anaerobic treatment feasibility of Sargassum muticum. Bioresour. Technol. 2015, 189, 53-61. [CrossRef] [PubMed]

34. Milledge, J.J.; Harvey, P.J. Ensilage and anaerobic digestion of Sargassum muticum. J. Appl. Phycol. 2016, 1-10. [CrossRef]

35. Yende, S.R.; Harle, U.N.; Chaugule, B.B. Therapeutic potential and health benefits of Sargassum species. Pharmacogn. Rev. 2014, 8, 1-7. [CrossRef] [PubMed]

36. Martinez Nadal, N.G. Antibiotic properties of Sargassum natans from Puerto Rico. J. Pharm. Sci. 1961, 50, 356. [CrossRef] [PubMed]

37. Wang, S.; Wang, Q.; Jiang, X.M.; Han, X.X.; Ji, H.S. Compositional analysis of bio-oil derived from pyrolysis of seaweed. Energy Conv. Manag. 2013, 68, 273-280. [CrossRef]

38. Demirel, Y. Energy and energy types. In Energy: Production, Conversion, Storage, Conservation, and Coupling; Springer London: London, UK, 2012; pp. 27-70.

39. Ross, A.B.; Jones, J.M.; Kubacki, M.L.; Bridgeman, T. Classification of macroalgae as fuel and its thermochemical behaviour. Bioresour. Technol. 2008, 99, 6494-6504. [CrossRef] [PubMed]

40. Merrill, A.L.; Watts, B.K. Energy Values of Foods: Basis \& Duration. Slight Revised February 1973; US Department of Agriculture: Washington, DC, USA, 1955.

41. Angell, A.R.; Mata, L.; Nys, R.; Paul, N.A. The protein content of seaweeds: A universal nitrogen-to-protein conversion factor of five. J. Appl. Phycol. 2015, 28, 511-524. [CrossRef]

42. Tiwari, B.; Troy, D. Seaweed Sustainability: Food and Non-Food Applications, 1st ed.; Academic Press: Amsterdam, The Netherlands, 2015.

43. Parimi, N.S.; Singh, M.; Kastner, J.R.; Das, K.C. Biomethane and biocrude oil production from protein extracted residual spirulina platensis. Energy 2015, 93, 697-704. [CrossRef]

44. González López, C.V.; Garcia, M.D.C.; Fernandez, F.G.A.; Bustos, C.S.; Chisti, Y.; Sevilla, J.M.F. Protein measurements of microalgal and cyanobacterial biomass. Bioresour. Technol. 2010, 101, 7587-7591. [CrossRef] [PubMed]

45. Heaven, S.; Milledge, J.; Zhang, Y. Comments on "anaerobic digestion of microalgae as a necessary step to make microalgal biodiesel sustainable". Biotechnol. Adv. 2011, 29, 164-167. [CrossRef] [PubMed]

46. Cao, Y.; Duan, J.; Guo, J.; Guo, S.; Zhao, J. Rapid determination of nucleosides, nucleobases and free amino acids in brown seaweeds using ultra-performance liquid chromatography coupled with triple quadrupole mass spectrometry. J. Appl. Phycol. 2014, 26, 675-686. [CrossRef]

47. Safi, C.; Charton, M.; Pignolet, O.; Pontalier, P.-Y.; Vaca-Garcia, C. Evaluation of the protein quality of Porphyridium cruentum. J. Appl. Phycol. 2013, 25, 497-501. [CrossRef]

48. Safi, C.; Charton, M.; Pignolet, O.; Silvestre, F.; Vaca-Garcia, C.; Pontalier, P.-Y. Influence of microalgae cell wall characteristics on protein extractability and determination of nitrogen-to-protein conversion factors. J. Appl. Phycol. 2013, 25, 523-529. [CrossRef]

49. Lourenco, S.O.; Barbarino, E.; Lavin, P.L.; Marque, U.M.L.; Aidar, E. Distribution of intracellular nitrogen in marine microalgae: Calculation of new nitrogen-to-protein conversion factors. Eur. J. Phycol. 2004, 39, 17-32. [CrossRef]

50. Phlips, E.J.; Zeman, C. Photosynthesis, growth and nitrogen-fixation by epiphytic forms of filamentous cyanobacteria from pelagic Sargassum. Bull. Mar. Sci. 1990, 47, 613-621.

51. Wernberg, T.; Thomsen, M.S.; Staehr, P.A.; Pedersen, M.F. Comparative phenology of Sargassum muticum and Halidrys siliquosa (phaeophyceae: Fucales) in limfjorden, Denmark. Bot. Mar. 2001, 44, 31-39. [CrossRef] 
52. Jard, G.; Marfaing, H.; Carrere, H.; Delgenes, J.P.; Steyer, J.P.; Dumas, C. French Brittany macroalgae screening: Composition and methane potential for potential alternative sources of energy and products. Bioresour. Technol. 2013, 144, 492-498. [CrossRef] [PubMed]

53. Becker, E.W. Micro-algae as a source of protein. Biotechnol. Adv. 2007, 25, 207-210. [CrossRef] [PubMed]

54. Holdt, S.; Kraan, S. Bioactive compounds in seaweed: Functional food applications and legislation. J. Appl. Phycol. 2011, 23, 543-597. [CrossRef]

55. Percival, E. The polysaccharides of green, red and brown seaweeds: Their basic structure, biosynthesis and function. Br. Phycol. J. 1979, 14, 103-117. [CrossRef]

56. Jung, K.A.; Lim, S.R.; Kim, Y.; Park, J.M. Potentials of macroalgae as feedstocks for biorefinery. Bioresour. Technol. 2013, 135, 182-190. [CrossRef] [PubMed]

57. Sun, J.C.; Tan, H.P. Alginate-based biomaterials for regenerative medicine applications. Materials 2013, 6, 1285-1309. [CrossRef]

58. Rehm, B.H.A. Alginates: Biology and Applications; Springer: Heidelberg, Germany, 2009.

59. Bixler, H.; Porse, H. A decade of change in the seaweed hydrocolloids industry. J. Appl. Phycol. 2011, 23, 321-335. [CrossRef]

60. Zhao, F.J.; Liu, F.L.; Liu, J.D.; Ang, P.O.; Duan, D.L. Genetic structure analysis of natural Sargassum muticum (fucales, phaeophyta) populations using RAPD and ISSR markers. J. Appl. Phycol. 2008, 20, 191-198. [CrossRef]

61. Liu, F.; Pang, S.J.; Gao, S.Q.; Shan, T.F. Intraspecific genetic analysis, gamete release performance, and growth of Sargassum muticum (fucales, phaeophyta) from China. Chin. J. Ocean. Limnol. 2013, 31, 1268-1275. [CrossRef]

62. Critchley, A.T.; Farnham, W.F.; Morrell, S.L. An account of the attempted control of an introduced marine alga, Sargassum-muticum, in southern England. Biol. Conserv. 1986, 35, 313-332. [CrossRef]

63. Gonzalez-Lopez, N.; Moure, A.; Dominguez, H. Hydrothermal fractionation of Sargassum muticum biomass. J. Appl. Phycol. 2012, 24, 1569-1578. [CrossRef]

64. Hoppe, H.A.; Levring, T.; Tanaka, Y. Marine Algae in Pharmaceutical Science; de Gruyter: Berlin, Germany; New York, NY, USA, 1979.

65. McHugh, D.J. A Guide to the Seaweed Industry; FAO: Rome, Italy, 2003.

66. Berteau, O.; Mulloy, B. Sulfated fucans, fresh perspectives: Structures, functions, and biological properties of sulfated fucans and an overview of enzymes active toward this class of polysaccharide. Glycobiology 2003, 13, 29-40. [CrossRef] [PubMed]

67. Rodriguez-Jasso, R.M.; Mussatto, S.I.; Pastrana, L.; Aguilar, C.N.; Teixeira, J.A. Chemical composition and antioxidant activity of sulphated polysaccharides extracted from Fucus vesiculosus using different hydrothermal processes. Chem. Pap. 2014, 68, 203-209. [CrossRef]

68. Gorham, J.; Lewey, S.A. Seasonal changes in the chemical composition of Sargassum muticum. Mar. Biol. 1984, 80, 103-107. [CrossRef]

69. Balboa, E.M.; Rivas, S.; Moure, A.; Dominguez, H.; Parajo, J.C. Simultaneous extraction and depolymerization of fucoidan from Sargassum muticum in aqueous media. Mar. Drugs 2013, 11, 4612-4627. [CrossRef] [PubMed]

70. Streefland, M. Report on Biofuel Production Processes from Micro, Macroalgae and Other Aquatic Biomass; AquaFUELs: Brussels, Belgium, 2010.

71. Milledge, J.J.; Smith, B.; Dyer, P.; Harvey, P. Macroalgae-derived biofuel: A review of methods of energy extraction from seaweed biomass. Energies 2014, 7, 7194-7222. [CrossRef]

72. Shekhar, S.H.S.; Lyons, G.; McRoberts, C.; McCall, D.; Carmichael, E.; Andrews, F.; McCormack, R. Brown seaweed species from Strangford Lough: Compositional analyses of seaweed species and biostimulant formulations by rapid instrumental methods. J. Appl. Phycol. 2012, 24, 1141-1157. [CrossRef]

73. Hardouin, K.; Burlot, A.S.; Umami, A.; Tanniou, A.; Stiger-Pouvreau, V.; Widowati, I.; Bedoux, G.; Bourgougnon, N. Biochemical and antiviral activities of enzymatic hydrolysates from different invasive French seaweeds. J. Appl. Phycol. 2014, 26, 1029-1042. [CrossRef]

74. Van Ginneken, V.J.T.; Helsper, J.; de Visser, W.; van Keulen, H.; Brandenburg, W.A. Polyunsaturated fatty acids in various macroalgal species from North Atlantic and tropical seas. Lipids Health Dis. 2011, 10, 104. [CrossRef] [PubMed]

75. University of Maryland Medical Centre. Docosahexaenoic Acid (DHA). Available online: http://www.umm. edu/altmed/articles/docosahexaenoic-acid-000300.htm (accessed on 9 September 2016). 
76. Milledge, J.J. Commercial application of microalgae other than as biofuels: A brief review. Rev. Environ. Sci. Biotechnol. 2011, 10, 31-41. [CrossRef]

77. Turner, J.P.; Rooker, J.R. Fatty acid composition of flora and fauna associated with Sargassum mats in the Gulf of Mexico. Mar. Biol. 2006, 149, 1025-1036. [CrossRef]

78. Khotimchenko, S.V. Fatty acid composition of seven Sargassum species. Phytochemistry 1991, 30, $2639-2641$. [CrossRef]

79. Bhaskar, N.; Hosakawa, M.; Miyashita, K. Growth inhibition of human pro-myelocytic leukemia (hl-60) cells by lipid extracts of marine alga Sargassum marginatum (fucales, phaeophyta) harvested off Goa (west coast of India) with special reference to fatty acid composition. Indian J. Mar. Sci. 2004, 33, 355-360.

80. Kim, G.W.; Itabashi, Y. Non-methylene-interrupted fatty acids with delta 5 unsaturation in Sargassum species. J. Oleo Sci. 2012, 61, 311-319. [CrossRef] [PubMed]

81. Banaimoon, S.A. Fatty-acids in marine macroalgae from southern Yemen (hadramout) including occurrence of eicosatetraenoic (20/4) and eicosapentaenoic (20/5) acids. Bot. Mar. 1992, 35, 165-168. [CrossRef]

82. Bazes, A.; Silkina, A.; Douzenel, P.; Fay, F.; Kervarec, N.; Morin, D.; Berge, J.-P.; Bourgougnon, N. Investigation of the antifouling constituents from the brown alga Sargassum muticum (yendo) fensholt. J. Appl. Phycol. 2009, 21, 395-403. [CrossRef]

83. Gerasimenko, N.I.; Martyyas, E.A.; Logvinov, S.V.; Busarova, N.G. Biological activity of lipids and photosynthetic pigments of Sargassum pallidum c. Agardh. Appl. Biochem. Microbiol. 2014, 50, 73-81. [CrossRef]

84. Clifton, P. Lowering cholesterol a review on the role of plant sterols. Aust. Fam. Phys. 2009, 38, $218-221$.

85. Genser, B.; Silbernagel, G.; de Backer, G.; Bruckert, E.; Carmena, R.; Chapman, M.J.; Deanfield, J.; Descamps, O.S.; Rietzschel, E.R.; Dias, K.C.; et al. Plant sterols and cardiovascular disease: A systematic review and meta-analysis (dagger). Eur. Heart J. 2012, 33, 444-451. [CrossRef] [PubMed]

86. Wang, P.R.; Xu, G.J.; Bian, L.Z.; Zhang, S.C.; Song, F.Q. Study on sterols from brown algae (Sargassum muticum). Chin. Sci. Bull. 2006, 51, 2520-2528. [CrossRef]

87. Reiner, E.; Topliff, J.; Wood, J.D. Hypocholesterolemic agents derived from sterols of marine algae. Can. J. Biochem. Physiol. 1962, 40, 1401-1406. [CrossRef] [PubMed]

88. Chen, Z.; Liu, J.; Fu, Z.; Ye, C.; Zhang, R.; Song, Y.; Zhang, Y.; Li, H.; Ying, H.; Liu, H. 24(s)-saringosterol from edible marine seaweed Sargassum fusiforme is a novel selective LXR $\beta$ agonist. J. Agric. Food Chem. 2014, 62, 6130-6137. [CrossRef] [PubMed]

89. Wijesinghe, W.; Jeon, Y.J. Biological activities and potential cosmeceutical applications of bioactive components from brown seaweeds: A review. Phytochem. Rev. 2011, 10, 431-443. [CrossRef]

90. Chae, D.; Manzoor, Z.; Kim, S.C.; Kim, S.; Oh, T.-H.; Yoo, E.-S.; Kang, H.-K.; Hyun, J.-W.; Lee, N.H.; Ko, M.-H.; et al. Apo-9'-fucoxanthinone, isolated from Sargassum muticum, inhibits CpG-induced inflammatory response by attenuating the mitogen-activated protein kinase pathway. Mar. Drugs 2013, 11, 3272-3287. [CrossRef] [PubMed]

91. Kumar, S.R.; Hosokawa, M.; Miyashita, K. Fucoxanthin: A marine carotenoid exerting anti-cancer effects by affecting multiple mechanisms. Mar. Drugs 2013, 11, 5130-5147. [CrossRef] [PubMed]

92. Gammone, M.A.; Riccioni, G.; D'Orazio, N. Carotenoids: Potential allies of cardiovascular health? Food Nutr. Res. 2015, 59, 26762. [CrossRef] [PubMed]

93. Maeda, H. Nutraceutical effects of fucoxanthin for obesity and diabetes therapy: A review. J. Oleo Sci. 2015, 64, 125-132. [CrossRef] [PubMed]

94. Zorofchian Moghadamtousi, S.; Karimian, H.; Khanabdali, R.; Razavi, M.; Firoozinia, M.; Zandi, K.; Abdul Kadir, H. Anticancer and antitumor potential of fucoidan and fucoxanthin, two main metabolites isolated from brown algae. Sci. World J. 2014, 2014, 768323. [CrossRef] [PubMed]

95. Mikami, K.; Hosokawa, M. Biosynthetic pathway and health benefits of fucoxanthin, an algae-specific xanthophyll in brown seaweeds. Int. J. Mol. Sci. 2013, 14, 13763-13781. [CrossRef] [PubMed]

96. Wang, C.; Kim, J.-H.; Kim, S.-W. Synthetic biology and metabolic engineering for marine carotenoids: New opportunities and future prospects. Mar. Drugs 2014, 12, 4810-4832. [CrossRef] [PubMed]

97. Balboa, E.M.; Soto, M.L.; Nogueira, D.R.; Gonzalez-Lopez, N.; Conde, E.; Moure, A.; Vinardell, M.P.; Mitjans, M.; Dominguez, H. Potential of antioxidant extracts produced by aqueous processing of renewable resources for the formulation of cosmetics. Ind. Crops Prod. 2014, 58, 104-110. [CrossRef] 
98. Suganya, T.; Varman, M.; Masjuki, H.H.; Renganathan, S. Macroalgae and microalgae as a potential source for commercial applications along with biofuels production: A biorefinery approach. Renew. Sustain. Energy Rev. 2016, 55, 909-941. [CrossRef]

99. Plouguerne, E.; le Lann, K.; Connan, S.; Jechoux, G.; Deslandes, E.; Stiger-Pouvreau, V. Spatial and seasonal variation in density, reproductive status, length and phenolic content of the invasive brown macroalga Sargassum muticum (yendo) fensholt along the coast of western Brittany (France). Aquat. Bot. 2006, 85, 337-344. [CrossRef]

100. Le Lann, K.; Jegou, C.; Stiger-Pouvreau, V. Effect of different conditioning treatments on total phenolic content and antioxidant activities in two Sargassacean species: Comparison of the frondose Sargassum muticum (yendo) fensholt and the cylindrical Bifurcaria bifurcata R. Ross. Phycol. Res. 2008, 56, 238-245. [CrossRef]

101. Tanniou, A.; Esteban, S.L.; Vandanjon, L.; Ibanez, E.; Mendiola, J.A.; Cerantola, S.; Kervarec, N.; la Barre, S.; Marchal, L.; Stiger-Pouvreau, V. Green improved processes to extract bioactive phenolic compounds from brown macroalgae using Sargassum muticum as model. Talanta 2013, 104, 44-52.

102. Dai, J.; Mumper, R.J. Plant phenolics: Extraction, analysis and their antioxidant and anticancer properties. Molecules 2010, 15, 7313-7352. [CrossRef] [PubMed]

103. Tabassum, M.R.; Xia, A.; Murphy, J.D. Seasonal variation of chemical composition and biomethane production from the brown seaweed Ascophyllum nodosum. Bioresour. Technol. 2016, 216, 219-226. [CrossRef] [PubMed]

104. Philippsen, A. Energy Input, Carbon Intensity, and Cost for Ethanol Produced from Brown Seaweed. Master's Thesis, University of Victoria, Victoria, BC, Canada, 2013.

105. Sridhar, S.; Rengasamy, R. Potential of seaweed liquid fertilizers (SLFS) on some agricultural crop with special reference to protein profile of seedlings. Int. J. Dev. Res. 2011, 1, 55-57.

106. BioMara. A Short History of Seaweed Exploitation in the Western British Isles. Available online: http:/ / www.biomara.org/understanding-seaweed/the-importance-of-seaweed-across-the-ages (accessed on 27 January 2014).

107. Besada, V.; Andrade, J.M.; Schultze, F.; González, J.J. Heavy metals in edible seaweeds commercialised for human consumption. J. Mar. Syst. 2009, 75, 305-313. [CrossRef]

108. Khaled, A.; Hessein, A.; Abdel-Halim, A.M.; Morsy, F.M. Distribution of heavy metals in seaweeds collected along Marsa-matrouh beaches, Egyptian Mediterranean sea. Egypt. J. Aquat. Res. 2014, 40, 363-371. [CrossRef]

109. Carro, L.; Barriada, J.L.; Herrero, R.; de Vicente, M.E.S. Interaction of heavy metals with ca-pretreated Sargassum muticum algal biomass: Characterization as a cation exchange process. Chem. Eng. J. 2015, 264, 181-187. [CrossRef]

110. Yokoi, K.; Konomi, A. Toxicity of so-called edible hijiki seaweed (Sargassum fusiforme) containing inorganic arsenic. Regul. Toxicol. Pharmacol. 2012, 63, 291-297. [CrossRef] [PubMed]

111. Nicholson, F.A.; Smith, S.R.; Alloway, B.J.; Carlton-Smith, C.; Chambers, B.J. An inventory of heavy metals inputs to agricultural soils in England and Wales. Sci. Total Environ. 2003, 311, 205-219. [CrossRef]

112. Ungureanu, G.; Santos, S.; Boaventura, R.; Botelho, C. Biosorption of antimony by brown algae S. muticum and A. nodosum. Environ. Eng. Manag. J. 2015, 14, 455-463.

113. Davis, T.A.; Volesky, B.; Mucci, A. A review of the biochemistry of heavy metal biosorption by brown algae. Water Res. 2003, 37, 4311-4330. [CrossRef]

114. Davis, T.A.; Volesky, B.; Vieira, R. Sargassum seaweed as biosorbent for heavy metals. Water Res. 2000, 34, 4270-4278. [CrossRef]

115. Mohapatra, B. Potential use of Sargassum species: An overview. In Sargassum Symposium; UWI, Cave Hill: Barbados, 2015.

116. Rubin, E.; Rodriguez, P.; Herrero, R.; Cremades, J.; Barbara, I.; de Vicente, M.E.S. Removal of methylene blue from aqueous solutions using as biosorbent Sargassum muticum: An invasive macroalga in Europe. J. Chem. Technol. Biotechnol. 2005, 80, 291-298. [CrossRef]

117. Rubin, E.; Rodriguez, P.; Herrero, R.; de Vicente, M.E.S. Biosorption of phenolic compounds by the brown alga Sargassum muticum. J. Chem. Technol. Biotechnol. 2006, 81, 1093-1099. [CrossRef]

118. Barbot, Y.; Thomsen, C.; Thomsen, L.; Benz, R. Anaerobic digestion of Laminaria japonica waste from industrial production residues in laboratory- and pilot-scale. Mar. Drugs 2015, 13, 5947. [CrossRef] [PubMed] 
119. Guadeloupe 1. Innovation: Un Bateau Contre Les Sargasses. Available online: http://la1ere.francetvinfo.fr/ guadeloupe/sites/regions_outremer/files/styles/top_big/public/assets/images/2015/08/18/sargator. jpg?itok=CUf6EtV1 (accessed on 17 March 2016).

120. Ward, A.J.; Lewis, D.M.; Green, B. Anaerobic digestion of algae biomass: A review. Algal Res. Biomass Biofuels Bioprod. 2014, 5, 204-214. [CrossRef]

121. Rocca, S.; Agostini, A.; Giuntoli, J.; Marelli, L. Biofuels from Algae: Technology Options, Energy Balance and Ghg Emissions: Insights from a Literature Review; Publications Office of the European Union: Luxembourg, 2015.

122. Milledge, J.J.; Heaven, S. Methods of energy extraction from microalgal biomass: A review. Rev. Environ. Sci. Biotechnol. 2014, 13, 301-320. [CrossRef]

123. Bruton, T.; Lyons, H.; Lerat, Y.; Stanley, M.; Rasmussen, M.B. A Review of the Potential of Marine Algae as a Source of Biofuel in Ireland; Sustainable Energy Ireland: Dublin, Ireland, 2009.

124. Milledge, J.J.; Harvey, P.J. Potential process "hurdles" in the use of macroalgae as feedstock for biofuel production in the British isles. J. Chem. Technol. Biotechnol. 2016, 91, 2221-2234. [CrossRef]

125. Aresta, M.; Dibenedetto, A.; Barberio, G. Utilization of macro-algae for enhanced $\mathrm{CO}_{2}$ fixation and biofuels production: Development of a computing software for an LCA study. Fuel Process. Technol. 2005, 86, 1679-1693. [CrossRef]

126. Fudholi, A.; Sopian, K.; Othman, M.Y.; Ruslan, M.H. Energy and exergy analyses of solar drying system of red seaweed. Energy Build. 2014, 68, 121-129. [CrossRef]

127. Valderrama, D.; Cai, J.; Hishamunda, N.; Ridler, N. Social and Economic Dimensions of Carrageenan Seaweed Farming; FAO Fisheries and Aquaculture technical paper 580; FAO: Rome, Italy, 2014.

128. Brennan, L.; Owende, P. Biofuels from microalgae-A review of technologies for production, processing, and extractions of biofuels and co-products. Renew. Sustain. Energy Rev. 2010, 14, 557-577. [CrossRef]

129. Oswald, W.J. Large-scale algal culture systems (engineering aspects). In Micro-Algal Biotechnology; Borowitzka, M.A., Borowitzka, L.J., Eds.; Cambridge University Press: Cambridge, UK, 1988.

130. Chan, J.C.C.; Cheung, P.C.K.; Ang, P.O. Comparative studies on the effect of three drying methods on the nutritional composition of seaweed Sargassum hemiphyllum (turn) C Ag. J. Agric. Food Chem. 1997, 45, 3056-3059. [CrossRef]

131. Gupta, S.; Cox, S.; Abu-Ghannam, N. Effect of different drying temperatures on the moisture and phytochemical constituents of edible Irish brown seaweed. LWT Food Sci. Technol. 2011, 44, 1266-1272. [CrossRef]

132. Ryckebosch, E.; Muylaert, K.; Eeckhout, M.; Ruyssen, T.; Foubert, I. Influence of drying and storage on lipid and carotenoid stability of the microalga Phaeodactylum tricornutum. J. Agric. Food. Chem. 2011, 59, 11063-11069. [CrossRef] [PubMed]

133. Indrawati, R.; Sukowijoyo, H.; Indriatmoko; Wijayanti, R.D.E.; Limantara, L. Encapsulation of brown seaweed pigment by freeze drying: Characterization and its stability during storage. Procedia Chem. 2015, 14, 353-360. [CrossRef]

134. Brennan, J.G.; Butters, J.R.; Cowell, N.D.; Lilly, A.E.V. Food Engineering Operation; Elsevier: London, UK, 1969.

135. Fellows, P. Food Processing Technology: Principles and Practice, 3rd ed.; CRC Press: Cambridge, UK; Woodhead Pub.: Boca Raton, FL, USA, 2009.

136. Molina Grima, E.; Belarbi, E.-H.; Acien-Fernandez, F.G.; Robles-Medina, A.; Yusuf, C. Recovery of microalgal biomass and metabolites: Process options and economics. Biotechnol. Adv. 2003, 20, 491-515. [CrossRef]

137. Seagate Products. Seaweed Powder. Available online: http://seagateproducts.com/product/229/SeaweedPowder-300-grams.html (accessed on 19 April 2016).

138. Ashbell, G.; Weinberg, Z.G. Silage Production and Utilization; FAO: Bet Dagan, Israel, 2005.

139. Oude Elferink, S.J.W.H.; Driehuis, F.; Gottschal, J.C.; Spoelstra, S.F. Silage fermentation processes and their manipulation. In FAO Electronic Conference on Tropical Silage; FAO: Rome, Italy, 1999.

140. Shinya, Y.; Yukihiko, M. The Asian Biomass Handbook-A Guide for Biomass Production and Utilization; The Japan Institute of Energy: Tokyo, Japan, 2008.

141. Jones, D.I.H.; Jones, R. The effect of crop characteristics and ensiling methodology on grass silage effluent production. J. Agric. Eng. Res. 1995, 60, 73-81. [CrossRef]

142. Black, W.A.P. The preservation of seaweed by ensiling and bactericides. J. Sci. Food Agric. 1955, 6, 14-23. [CrossRef] 
143. Uchida, M.; Miyoshi, T. Algal fermentation-the seed for a new fermentation industry of foods and related products. Jarq Jpn. Agric. Res. Q. 2013, 47, 53-63. [CrossRef]

144. Herrmann, C.; FitzGerald, J.; O'Shea, R.; Xia, A.; O'Kiely, P.; Murphy, J.D. Ensiling of seaweed for a seaweed biofuel industry. Bioresour. Technol. 2015, 196, 301-313. [CrossRef] [PubMed]

145. Driehuis, F.; van Wikselaar, P.G. The occurrence and prevention of ethanol fermentation in high-dry-matter grass silage. J. Sci. Food Agric. 2000, 80, 711-718. [CrossRef]

146. Bastiman, B. Factors affecting silage effluent production. Exp. Husb. 1977, 40-46.

147. Ministry of Agriculture, Forestry and Fisheries. Environmental Impacts of Baled Silage; WA 0111; MAFF: Tokyo, Japan, 1999.

148. Mannetje, L. Silage for animal feed. In Encyclopedia of Life Support Systems; Eolss Publishers: Oxford, UK, 2010; Volume 8, pp. 123-135.

149. Woolf, D.; Lehmann, J.; Fisher, E.M.; Angenent, L.T. Biofuels from pyrolysis in perspective: Trade-offs between energy yields and soil-carbon additions. Environ. Sci. Technol. 2014, 48, 6492-6499. [CrossRef] [PubMed]

150. Meyer, S.; Glaser, B.; Quicker, P. Technical, economical, and climate-related aspects of biochar production technologies: A literature review. Environ. Sci. Technol. 2011, 45, 9473-9483. [CrossRef] [PubMed]

151. Tenenbaum, D.J. Biochar: Carbon mitigation from the ground up. Environ. Health Perspect. 2009, 117, 70-73. [CrossRef]

152. Shackley, S.; Sohi, S. An Assessment of the Benefits and Issues Associated with the Application of Biochar to Soil; UK Biochar Research Centre: Edinburgh, UK, 2010.

153. Van der Kolk, J.; Zwart, K. Pyrolysis in the Countries of the North Sea Region. Potentially Available Quantities of Biomass Waste for Biochar Production. A Publication of the Interreg IVB Project Biochar: Climate saving soils. 2013. Available online: http://www.biochar-interreg4b.eu/images/file/WP44\%20-\%20Pyrolysis\%20in\% 20the\%20Countries\%20of\%20the\%20North\%20Sea\%20Region.pdf (accessed on 9 September 2016).

154. McKendry, P. Energy production from biomass (part 2): Conversion technologies. Bioresour. Technol. 2002, 83, 47-54. [CrossRef]

155. Saidur, R.; Abdelaziz, E.A.; Demirbas, A.; Hossain, M.S.; Mekhilef, S. A review on biomass as a fuel for boilers. Renew. Sust. Energy Rev. 2011, 15, 2262-2289. [CrossRef]

156. Peacocke, C.; Joseph, S. Notes on Terminology and Technology in Thermal Conversion. Available online: http://www.biochar-international.org/publications/IBI\#Pyrolysis_guidelines (accessed on 15 April 2014).

157. Scott, H.L.; Ponsonby, D.; Atkinson, C.J. Biochar: An improver of nutrient and soil water availability-What is the evidence? CAB Rev. 2014, 9. [CrossRef]

158. Roberts, D.A.; Paul, N.A.; Dworjanyn, S.A.; Bird, M.I.; de Nys, R. Biochar from commercially cultivated seaweed for soil amelioration. Sci. Rep. 2015, 5, 9665. [CrossRef] [PubMed]

159. Bird, K.T.; Benson, P.H. Seaweed Cultivation for Renewable Resources; Elsevier: Amsterdam, The Netherlands, 1987.

160. Keita, J.D. Wood or charcoal—Which is better? Int. J. For. For. Ind. 1987, 39, 61-66.

161. Demirbas, A. Biomass resource facilities and biomass conversion processing for fuels and chemicals. Energy Conv. Manag. 2001, 42, 1357-1378. [CrossRef]

162. Yu, L.J.; Wang, S.; Jiang, X.M.; Wang, N.; Zhang, C.Q. Thermal analysis studies on combustion characteristics of seaweed. J. Therm. Anal. Calorim. 2008, 93, 611-617. [CrossRef]

163. Wang, S.; Jiang, X.M.; Wang, Q.; Han, X.X.; Ji, H.S. Experiment and grey relational analysis of seaweed particle combustion in a fluidized bed. Energy Conv. Manag. 2013, 66, 115-120. [CrossRef]

164. Huang, G.; Chen, F.; Wei, D.; Zhang, X.; Chen, G. Biodiesel production by microalgal biotechnology. Appl. Energy 2010, 87, 38-46. [CrossRef]

165. Bahadar, A.; Bilal Khan, M. Progress in energy from microalgae: A review. Renew. Sustain. Energy Rev. 2013, 27, 128-148. [CrossRef]

166. Murphy, F.; Devlin, G.; Deverell, R.; McDonnell, K. Biofuel production in Ireland-An approach to 2020 targets with a focus on algal biomass. Energies 2013, 6, 6391-6412. [CrossRef]

167. Van der Wal, H.; Sperber, B.L.H.M.; Houweling-Tan, B.; Bakker, R.R.C.; Brandenburg, W.; López-Contreras, A.M. Production of acetone, butanol, and ethanol from biomass of the green seaweed Ulva lactuca. Bioresour. Technol. 2013, 128, 431-437. [CrossRef] [PubMed]

168. Singh, J.; Gu, S. Biomass conversion to energy in India-a critique. Renew. Sust. Energ. Rev. 2010, 14, 1367-1378. [CrossRef] 
169. Ventura, J.-R.S.; Yang, B.; Lee, Y.-W.; Lee, K.; Jahng, D. Life cycle analyses of $\mathrm{CO}_{2}$, energy, and cost for four different routes of microalgal bioenergy conversion. Bioresour. Technol. 2013, 137, 302-310. [CrossRef] [PubMed]

170. Delrue, F.; Seiter, P.A.; Sahut, C.; Cournac, L.; Roubaud, A.; Peltier, G.; Froment, A.K. An economic, sustainability, and energetic model of biodiesel production from microalgae. Bioresour. Technol. 2012, 111, 191-200. [CrossRef] [PubMed]

171. Lewis, J.; Salam, F.; Slack, N.; Winton, M.; Hobson, L. Product Options for the Processing of Marine Macro-Algae-Summary Report; The Crown Estates: London, UK, 2011.

172. Langlois, J.; Sassi, J.F.; Jard, G.; Steyer, J.P.; Delgenes, J.P.; Helias, A. Life cycle assessment of biomethane from offshore-cultivated seaweed. Biofuels Bioprod. Biorefining 2012, 6, 387-404. [CrossRef]

173. Yokoyama, S.; Jonouchi, K.; Imou, K. Energy production from marine biomass: Fuel cell power generation driven by methane produced from seaweed. Int. J. Environ. Ecol. Geol. Geophys. Eng. 2007, 1, $24-27$.

174. Alvarado-Morales, M.; Boldrin, A.; Karakashev, D.B.; Holdt, S.L.; Angelidaki, I.; Astrup, T. Life cycle assessment of biofuel production from brown seaweed in Nordic conditions. Bioresour. Technol. 2013, 129, 92-99. [CrossRef] [PubMed]

175. Chen, H.; Zhou, D.; Luo, G.; Zhang, S.; Chen, J. Macroalgae for biofuels production: Progress and perspectives. Renew. Sustain. Energy Rev. 2015, 47, 427-437. [CrossRef]

176. Golueke, C.G.; Oswald, W.J.; Gotaas, H.B. Anaerobic digestion of algae. Appl. Microbiol. 1957, 5, 47-55. [PubMed]

177. Nallathambi Gunaseelan, V. Anaerobic digestion of biomass for methane production: A review. Biomass Bioenergy 1997, 13, 83-114. [CrossRef]

178. Banks, C.; Zhang, Y. Optimising Inputs and Outputs from Anaerobic Digestion Processes-Technical Report; Defra: Southampton, UK, 2010.

179. Nguyen, H.; Heaven, S.; Banks, C. Energy potential from the anaerobic digestion of food waste in municipal solid waste stream of urban areas in Vietnam. Int. J. Energy Environ. Eng. 2014, 5, 365-374. [CrossRef]

180. Astals, S.; Musenze, R.S.; Bai, X.; Tannock, S.; Tait, S.; Pratt, S.; Jensen, P.D. Anaerobic co-digestion of pig manure and algae: Impact of intracellular algal products recovery on co-digestion performance. Bioresour. Technol. 2015, 181, 97-104. [CrossRef] [PubMed]

181. Sutherland, A.; Varela, J. Comparison of various microbial inocula for the efficient anaerobic digestion of Laminaria hyperborea. BMC Biotechnol. 2014, 14, 7. [CrossRef] [PubMed]

182. Van Hal, J.W.; Huijgen, W.J.J.; Lopez-Contreras, A.M. Opportunities and challenges for seaweed in the biobased economy. Trends Biotechnol. 2014, 32, 231-233. [CrossRef] [PubMed]

183. Baghel, R.S.; Trivedi, N.; Gupta, V.; Neori, A.; Chennur, R.R.; Lali, A.M.; Jha, B. Biorefining of marine macroalgal biomass for production of biofuel and commodity chemicals. Green Chem. 2015, 17, 2436-2443. [CrossRef]

184. Kelly, M.S.; Dworjanyn, S. The Potential of Marine Biomass for Anaerobic Biogas Production a Feasibility Study with Recommendations for Further Research; The Crown Estate on behalf of the Marine Estate: Scotland, UK, 2008.

185. Smit, A. Medicinal and pharmaceutical uses of seaweed natural products: A review. J. Appl. Phycol. 2004, 16, 245-262. [CrossRef]

186. Murphy, C.; Hotchkiss, S.; Worthington, J.; McKeown, S. The potential of seaweed as a source of drugs for use in cancer chemotherapy. J. Appl. Phycol. 2014, 26, 2211-2264. [CrossRef]

187. Blunt, J.W.; Copp, B.R.; Keyzers, R.A.; Munro, M.H.G.; Prinsep, M.R. Marine natural products. Nat. Prod. Rep. 2015, 32, 116-211. [CrossRef] [PubMed]

188. Oliveira, J.V.; Alves, M.M.; Costa, J.C. Optimization of biogas production from Sargassum sp. Using a design of experiments to assess the co-digestion with glycerol and waste frying oil. Bioresour. Technol. 2015, 175, 480-485. [CrossRef] [PubMed]

(C) 2016 by the authors; licensee MDPI, Basel, Switzerland. This article is an open access article distributed under the terms and conditions of the Creative Commons Attribution (CC-BY) license (http:/ / creativecommons.org/licenses/by/4.0/). 